Максилович А. М., аспірант наукової лабораторї з проблем превентивної діяльності та запобігання корупиї Національної академії внутрішніх справ

\title{
ОСОБЛИВОСТІ АДМІНІСТРАТИВНО-ПРАВОВОГО СТАТУСУ ДИСЦИПЛІНАРНОЇ КОМІСІї ДЕРЖАВНОГО БЮРО РОЗСЛІДУВАНЬ
}

\begin{abstract}
Анотація. У статті зроблено спробу з'ясувати особливості адміністративно-правового статусу Дисциплінарної комісії Державного бюро розслідування. Обгрунтовано, що необхідність дослідження особливостей адміністративно-правового статусу Дисциплінарної комісії Державного бюро розслідування викликана також тим, що така категорія відображає специфіку організації та діяльності Дисциплінарної комісії Державного бюро розслідування, особливо в контексті посилення її ролі у застосуванні дисциплінарних стягнень до працівників Державного бюро розслідування. У сучасній адміністративно-правовій науці тематика дослідження функціонування Дисциплінарної комісії Державного бюро розслідування належить до малорозроблених та не визначених. Тому усвідомлення теоретичних і практичних аспектів адміністративно-правового статусу Дисциплінарної комісії Державного бюро розслідування зумовлює потребу у проведенні спеціалізованих наукових досліджень у цій сфері. Наведено визначення поняття «адміністративно-правовий статус Дисциплінарної комісії Державного бюро розслідування», запропоновано виокремлювати структурні елементи у складі такого статусу, охарактеризовано ї зміст. Визначено, що під адміністративно-правовим статусом Дисциплінарної комісії Державного бюро розслідування слід розуміти правове положення осіб у складі Дисциплінарної комісії Державного бюро розслідування, що визначається за допомогою закріплення у чинному адміністративному законодавстві мети іiі утворення та організації діяльності, завдань, функцій, компетенції та відповідальності, що дозволяє ӥй бути повноцінним учасником адміністративно-правових, у тому числі і службових відносин. Основними структурними елементами адміністративно-правового статусу Дисциплінарної комісії Державного бюро розслідування є: мета іiі утворення; завдання, функції, компетенція та юридична відповідальність. Істотною рисою названих структурних елементів адміністративно-правового статусу Дисциплінарної комісії Державного бюро розслідування є урегульованість спеціальними нормами адміністративного права, їх самостійність (кожен із них має власне призначення), відносна стабільність у часі, взаємозв'язок і взаємозалежність один від одного.
\end{abstract}

Ключові слова: дисципліна, службова дисципліна, дисциплінарна відповідальність, державний службовець, працівник Державного бюро розслідування, дисциплінарний проступок, дисциплінарне стягнення, адміністративно-правове регулювання, адміністративно-правовий статус, дисциплінарна комісія.

Важливу цінність питань, пов'язаних із дисциплінарними провадженнями у сфері діяльності Державного бюро розслідування (далі - ДБР), становить механізм притягнення пра- цівників ДБР до дисциплінарної відповідальності. Ключовим елементом забезпечення належного рівня якості практичної реалізації зазначеної процедури є особливості, пов' язані насамперед із діяльністю суб' єктів ії здійснення, одним із яких є Дисциплінарна комісія ДБР. Відсутність належного рівня адміністративно-правового регулювання діяльності Дисциплінарної комісії ДБР зумовлює актуальність комплексного науково-теоретичного дослідження особливостей адміністративно-правового статусу Дисциплінарної комісії ДБР та визначення можливих шляхів його подальшого вдосконалення. Окрім того, така необхідність викликана також тим, що категорія адміністративно-правового статусу відображає специфіку організації та діяльності Дисциплінарної комісії ДБР, особливо в контексті посилення іiі ролі у застосуванні дисциплінарних стягнень до працівників ДБР. Водночас варто зауважити, що у сучасній адміністративно-правовій науці тематика дослідження функціонування Дисциплінарної комісії ДБР належить до малорозроблених та невизначених. Тому усвідомлення теоретичних і практичних аспектів адміністративно-правового статусу Дисциплінарної комісії ДБР зумовлює потребу у проведенні спеціалізованих наукових досліджень у цій сфері.

Слід здійснити аналіз поняття «адміністративно-правовий статус», з'ясувати та охарактеризувати його структурні елементи, а також визначити особливості адміністративно-правового статусу Дисциплінарної комісії ДБР. Адміністративно-правовий статус $є$ складним правовим феноменом, який відображає специфіку правового становища суб'єкта правовідносин у державі та суспільстві і зв'язки між ними. Традиційно в правовій доктрині є вказівка на те, що правовий статус $є$ вихідним пунктом, з якого необхідно починати аналіз будь-яких суб'єктів правовідносин. Відповідно до теорії адміністративного права, «суб'єктом адміністративно-правових відносин прийнято вважати фізичну або юридичну особу, носія прав і обов'язків у сфері публічного управління, передбачених адміністративно-правовими нормами, що здатний до реалізації власних прав та виконання покладених на нього обов'язків» [1, с. 226]. Дисциплінарна комісія ДБР, згідно 3 положеннями чинного законодавства, наділена функціями дисциплінарного провадження щодо працівників ДБР, а тому цілком аргументовано може бути віднесена до числа суб'єктів адміністративного права, який у спеціально встановленому порядку набув адміністративної правосуб'єктності. Так, відповідно ст. 25 Закону України від 12.11.2015 р. «Про Державне бюро розслідувань» для розгляду питань застосування дисциплінарних стягнень до працівників ДБР утворюється спеціальний орган - Дисциплінарна комісія ДБР. Склад та положення про Дисциплінарну комісію ДБР затверджуються Директором 
ДБР. Дисциплінарна комісія на підставі службового розслідування, що проводиться підрозділом внутрішнього контролю, складає висновок про наявність чи відсутність у діях працівника ДБР дисциплінарного проступку та підстав для його притягнення до дисциплінарної відповідальності з визначенням рекомендованого виду дисциплінарного стягнення [2]. 3 огляду на це, слід зазначити, що Дисичиллінарна комісія ДБР є постійно діючим, колегіальним органом, створеним при ДБР, уповноваженим для розгляду матеріалів службового розслідування і дослідження фактів, щзо стосуються проступку праиівника ДБР, з метою всебічного, повного і об'єктивного встановлення обставин вчинення дисииплінарного проступку i винесення рекомендацій про застосування дисииплінарного стягнення до особи, яка його вчинила.

Для з'ясування сутності поняття «адміністративно-правовий статус» Дисциплінарної комісії ДБР слід звернутися до етимологічного розуміння слова «статус», яке походить від латинського «status» і перекладається як становище та означає положення, стан чого-небудь або будь-кого [3, с. 578]. Сучасні словниково-довідникові джерела тлумачать поняття «статус» у різних значеннях, але в юридичному контексті воно означає: правове становище громадян, громадських і державних підприємств, установ, організацій тощо; сукупність прав та обов'язків фізичних або юридичних осіб [4, с. 545; 5, с. 355; 6, с. 506; 7, с. 626]. Отже, загальне, базове пояснення терміна «статус» характеризує правове становище (правове положення) особи (фізичної/юридичної) взагалі у певній системі та виражається здебільшого у сукупності прав та обов'язків.

Сутність поняття «правовий статус» $є$ предметом дослідження переважно у теорії права. Так, О.Ф. Скакун під правовим статусом розуміє «систему закріплених у нормативно-правових актах і гарантованих державою прав, свобод, обов'язків, відповідальності, відповідно до яких індивід як суб'єкт права (тобто як такий, що має правосуб'єктність) координує свою поведінку в суспільстві» [8, с. 59]. К.Г. Волинка вважає, що правовий статус включає в себе «права, свободи і обов'язки особи. Він впливає на формування відповідних відносин між індивідом, суспільством і державою» [9, с. 207]. О.В. Зайчук та Н.М. Оніщенко вказують, що правовий статус $є$ «системою законодавчо встановлених і гарантованих державою прав, свобод, законних інтересів та обов'язків особи» [10, с. 78]. До характерних ознак правового статусу вони відносять: «1) універсальність (поширюється на всіх суб'єктів права); 2) специфічність (відображає індивідуальні особливості суб'єктів права й учасників правовідносин, які впливають на характер i розвиток останніх); 3) нерозривний взаємозв'язок елементів системи правового статусу (права та свободи не можуть реалізуватись без обов'язків та відповідальності); 4) системність (забезпечує системність прав, свобод та обов'язків)» [10, с. 79]. А.В. Малько та Н.I. Матузов дещо по-іншому інтерпретують правовий статус: «комплексна інтеграційна категорія, яка відображає взаємовідносини суб' єктів суспільних відносин, особи i суспільства, громадянина і держави, індивіда та колективу, а також інші соціальні зв'язки» [11, с. 397]. А.М. Завальний та О.А. Колодій пропонують визначення правового статусу як «закріплене правове положення фізичних та юридичних осіб у певній системі суспільних відносин» [12, с. 202]. На їхню думку, структура правового статусу включає: «правові норми та принципи, що встановлюють цей статус; правосуб' єктність; основні права, свободи та обов'язки; правові принципи і правові гарантії; законні інтереси; громадянство (або інший зв'язок чи відношення до держави); юридичну відповідальність» $[12$, c. 202]. Правовий статус - це врегульоване нормами права правове становище суб'єкта суспільних відносин, зміст якого формується залежно від сфери правовідносин. Зважаючи на це, O.І. Безпалова, Д.О. Горбач наголошують на тому, що «більш точний зміст правового статусу формують норми галузей права: конституційного, адміністративного, кримінального, цивільного тощо. Відповідно виділяють різні правові статуси, в тому числі адміністративно-правовий. Адміністративно-правовий статус є одним із видів загального поняття «правовий статус», який також може бути конкретизований залежно від виду суб'єктів адміністративно-правових відносин: фізичні або юридичні особи. Крім того, слід враховувати те, що у юридичних осіб є власна система, що дозволяє виділити органи державної влади» $[13$, с. 32]. Отже, залежно від характеру та специфіки правовідносин категорія правового статусу набуває власної специфіки, тобто якщо правовідносини регулюються нормами адміністративного права, то учасники правовідносин, окрім загального для всіх правового статусу, мають і його окремий підвид - адміністративно-правовий статус.

Аналіз наукових поглядів щодо розуміння поняття «адміністративно-правовий статус» як складної багатогранної юридичної категорії дає підстави констатувати відсутність єдиної позиції серед учених-адміністративістів. У наукових колах розрізняють два самостійних поняття: правовий статус особи у «вузькому» (складається 3 прав та обов'язків) та у «широкому» (включається весь обсяг правових можливостей і обтяжень суб'єкта, а також правові засоби, що характеризують різноманітні сторони його правового положення) сенсах [14, с. 156-162]. За таким підходом більшість науковців переконана в тому, що адміністративно-правовий статус особи розкривається через характеристику його елементів. Ю.П. Битяк зазначає, що адміністративно-правовий статус $€$ «складовою частиною загального статусу ... та встановлюється обсягом і характером його адміністративної правосуб'єктності, яку становлять адміністративна правоздатність і адміністративна дієздатність» $[15$, с. 58]. І.П. Голосніченко вказує, що зміст адміністративно-правового статусу становить «комплекс прав і обов'язків, закріплених у нормах адміністративного права, реалізація яких забезпечується певними гарантіями» [16, с. 198]. Зі свого боку В.В. Зуй надає значно ширший перелік елементів адміністративно-правового статусу: «права, обов'язки, гарантії діяльності, юридична відповідальність, завдання, цілі, функції, компетенція, порядок формування та процедури діяльності» [17, с. 107]. О.М. Бандурка вважає, що «адміністративно-правовий статус - це сукупність прав, обов'язків і гарантій їх реалізації, закріплених у нормах адміністративного права» [18, с. 144]. Схоже визначення надає С.Г. Стеценко: «адміністративно-правовий статус являє собою сукупність прав, обов'язків і гарантій їх реалізації, що визначені у нормативних актах» $[19$, с. 90]. На думку Т.О. Коломоєць, адміністративно-правовий статус є сукупністю суб'єктивних прав і обов'язків, закріплених нормами адміністративного права за певним органом» [20, с. 64]. Слід зауважити, що науковці, окрім формулювання змісту загальної категорії адміністративно-правового статусу, притаманного учасникам адміністративних правовідносин, пропонують виокремлювати 
складові елементи адміністративно-правового статусу конкретного суб'єкта $з$ одночасною конкретизацією його належності відповідному суб'єкту. Так, В.В. Галунько наголошує на тому, що «адміністративно-правовий статус державного службовця полягає в сукупності їхніх прав і обов'язків, порядку призначення і звільнення, порядку проходження служби, а також в особливостях дисциплінарної відповідальності» [21, с. 128]. С.Л. Курило відзначає, що під адміністративно-правовим статусом органів внутрішніх справ слід розуміти їхнє «положення (становище) у системі суспільних відносин та механізмі державного управління, що визначається державою шляхом закріплення в нормах адміністративного законодавства їхніх завдань, функцій, повноважень та відповідальності, які реалізуються зазначеними суб' єктами через відповідні адміністративно-правові (управлінські) відносини, зокрема, ті, що складаються безпосередньо під час їхньої взаємодії з питань забезпечення громадської безпеки та громадського порядку» [22, с. 526]. М.С. Моісєєв визначає адміністративно-правовий статус ДБР як «сукупність закріплених на законодавчому рівні i конкретизованих нормами адміністративного законодавства елементів, що визначають особливості створення та діяльності ДБР, межі здійснення покладених на нього завдань та функцій, його місце в механізмі держави, а також у відносинах 3 іншими державними і недержавними суб'єктами» [23, с. 80]. На підставі вищезазначеного можна стверджувати, що категорія «адміністративно-правовий статус» охоплює різні елементи, основними 3 яких є права та обов'язки, що знаходять своє втілення у чинному адміністративному законодавстві. Але, досліджуючи зміст адміністративно-правового статусу, вчені розширюють перелік складових елементів, відносять до них завдання, цілі, функції, компетенцію, відповідальність тощо. Так, В.Я. Малиновський підкреслює, що основними елементами адміністративно-правового статусу є «завдання, цілі, компетенція, відповідальність, порядок формування та процедури діяльності» [24, с. 255]. С.В. Ківалов відносить до змісту «адміністративно-правового статусу: функції, завдання, компетенцію» [25, с. 145]. Тому інша позиція науковців, яку не можна віднести до класичного підходу, стосується того, що структуру адміністративно-правового статусу детально розглядають крізь призму поняття «компетенції». Так, наприклад, В.Б Авер'янов визнає, що «компетенція (права та обов'язки) є головною складовою частиною змісту правового статусу кожного органу, яка доповнюється такими важливими елементами, як: завдання, функції, характер взаємозв'язків 3 іншими органами (як по «вертикалі», так і по «горизонталі»), місце в ієрархічній структурі органів виконавчої влади, порядок вирішення кадрових питань тощо» [14, с. 247]. Фахівці з теорії права висловлюють думку, що компетенція - це права та обов'язки (повноваження), фахівці $з$ адміністративного права часто відносять до складників компетенції повноваження, предмети відання, функції, завдання органу, відповідальність [26, с. 196]. А.В. Венедиктов, ототожнюючи компетенцію та адміністративну правосуб' єктність уточнює, що компетенція виступає предметом діяльності будь-якого державного органу і в обов'язковому порядку повинна містити завдання та функції [27, с. 613]. Ю.О. Тихомиров вважає, що компетенція - це «комплекс легально встановлених способів здійснення публічних функцій» [28, с. 24]. На його думку, вона складається 3 компетенційних елементів: нормативно визначених завдань; предметів відання (як юри- дично визначених сфер і об'єктів впливу); владних повноважень (як гарантованих законом заходів прийняття рішень і вчинення дій), а також супутнього елемента - відповідальності за їх невиконання [29, с. 55-56]. О.В. Пономарьов поділяе зміст компетенції на основні та додаткові елементи компетенції. До основних елементів компетенції відносить виключно повноваження, додатковими вважає предмет відання та просторово-територіальні межі дії [30, с. 11]. А.В. Солонар стверджує, що «поняття завдань, функцій, повноважень і компетенції перебувають між собою у взаємозв'язку. Оскільки всі державні чи недержавні органи створюються 3 певною метою їхньої діяльності, в завданнях суб'єкта безпосередньо відображається ця мета. Проте без функцій, завдяки яким реалізуються поставлені завдання, мета суб'єкта залишається лише на папері. Тому для виконання функцій кожний орган наділяється правами та обов'язками, які можна окреслити поняттям «повноваження». Сукупність перерахованих структурних елементів становить поняття «компетенції» [31]. М.I. Карпа визначає компетенцію як «один з інструментів для реалізації функцій публічної служби. Автор наголошує, що компетенція визначає обсяг та зміст діяльності суб'єкта; здійснює розмежування функцій між різними суб' єктами; встановлює певний розподіл функцій, які реалізуються публічною службою загалом. Тобто компетенцією публічної служби з позиції зв'язку функцій та компетенцій суб'єктів публічної служби вважає сукупністю встановлених нормативними правовими актами завдань, функцій публічних суб'єктів, прав та обов'язків посадових осіб, які перебувають на публічній службі щодо здійснення встановлених функцій» [32, с. 45]. Під час визначення адміністративно-правового статусу Дисциплінарної комісії ДБР доцільним є врахування компетенції, яка являє собою сукупність нормативно закріплених державно-владних повноважень, тобто обсяг публічно-правових функцій, покладених на цей орган, або коло чітко визначених завдань, передбачених законодавством, які він має право вирішувати для реалізації визначених цілей.

3 огляду на специфіку дослідження, для характеристики змістовної складової частини адміністративно-правового статусу Дисциплінарної комісії ДБР як складної юридично-теоретичної конструкції, окрім компетенції необхідно виділити інші його структурні елементи, які взаємопов'язані з цим поняттям, а саме: мета іiі утворення, завдання, функції, юридична відповідальність. Більш детальний розгляд зазначених структурних елементів допоможе зрозуміти їх сутність. Так, поняття «мета» $\mathrm{i}$ «завдання» визначається одне за допомогою іншого. Великий тлумачний словник сучасної української мови трактує «мету» таким чином: «це те, до чого хтось прагне, чого хоче досягти; ціль; заздалегідь намічене завдання; замисел» [33, с. 661]. У свою чергу, слово «завдання» тлумачиться як «наперед визначений, запланований для виконання обсяг роботи, справа тощо; настанова, розпорядження, виконати певне доручення; мета, до якої прагнуть; те, що хочуть здійснити» [33, с. 378]. Однак, враховуючи юридичну спрямованість дослідження, найбільший інтерес представляють позиції вчених-юристів щодо визначення сутності поняття «мета» та його співвідношення з поняттям «завдання» у діяльності різних суб' єктів:

- мета являє собою образ, інформаційну модель бажаного результату, а завдання - це похідна із закону об'єктивно існуюча форма реалізації правової компетенції, яка реалізується суб'єктами, що наділені відповідними повноваженнями 
та здійснюють свою діяльність із метою досягнення окремого та загального правового результату [34, с. 75];

- мета - це певний задум, якого слід прагнути досягти; завдання - це те, що потрібно виконати, розв'язати, це ті конкретні питання, які необхідно вирішити, щоб досягти поставленої мети [35, с. 142];

- мета - це бажаний і необхідний результат, якого треба досягти або який необхідно зберегти, а завдання є засобом досягнення того, що необхідно зробити для досягнення результату (в межах однієї мети може бути сформульовано декілька завдань) [36, с. 78];

- мета - це задум, намір, те, чого необхідно досягти, а завдання - конкретна діяльність, спрямована на досягнення поставленої мети [37, с. 32];

- завдання являє собою активізовану, конкретизовану та сформовану перед кимось або чимось мету (ціль) [38, с. 57];

- завдання - це мета, досягнення якої є бажаним до відповідного моменту в межах періоду, на який розраховано управлінське рішення. Завдання указує на безпосередню мету організації, що піддається кількісній характеристиці [39, с. 99]. О.М. Литвинов відстоює позицію, згідно з якою «завдання визначаються цілями, витікають із них» [40, с. 34-35]. На думку вченого, «мета формує конкретні завдання соціального суб'єкта в реалізації його інтересів. Зміст поняття «завдання» включає можливість з'ясування причин недосягнення мети. Це необхідно для того, щоб органи та посадовці, уповноважені суспільством (державою) здійснювати відповідну діяльність, орієнтувалися у відповідних процесах і процедурах, а в окремих випадках могли обгрунтовано відмовитися від реалізації певних повноважень. Зазначене може відбутися в тому разі, якщо немає об'єктивної можливості погоджувати ідеальну модель майбутнього результату з реальною можливістю його досягнення або привернути для реалізації завдань необхідні та достатні засоби й ресурси» [41, с. 34-35]. На відміну від індивідуальних суб' єктів, правовий статус колективних суб'єктів - державних органів як суб'єктів правовідносин - обмежується тими цілями і завданнями, заради яких вони створюються. Специфіка виконання повноважень державними органами полягає у тому, що вони діють у підсистемі публічного права (конституційне, адміністративне право), для якого характерним $є$ імперативний метод - юридичної субординації і підпорядкованості [32, с. 29]. Таким чином, аналіз вищенаведених позицій свідчить про те, що такі категорії, як «мета» i «завдання», є взаємозв'язаними та зумовлюють одна одну. А тому мета діяльності Дисциплінарної комісії ДБР деталізується в конкретних завданнях відповідного державного органу. Метою діяльності Дисциплінарної комісії ДБР здійснення дисциплінарного провадження задля визначення ступеня вини, характеру і тяжкості вчиненого дисциплінарного проступку 3 дотриманням принципів законності, об' єктивності, рівності, всебічності під час дисциплінарного провадження. Основним завданням Дисциплінарної комісії ДБР є розгляд питань застосування дисциплінарних стягнень до працівників ДБР. Дисциплінарна комісія ДБР відповідно до покладених на неї завдань складає висновок про наявність чи відсутність у діях працівника ДБР дисциплінарного проступку та підстав для його притягнення до дисциплінарної відповідальності з визначенням рекомендованого виду дисциплінарного стягнення на підставі службового розслідування, що проводиться підрозділом вну- трішнього контролю. Організаційне та матеріально-технічне забезпечення Дисциплінарної комісії ДБР здійснює ДБР.

Нормативно визначена мета (цілі) й завдання Дисциплінарної комісії ДБР дають змогу виділити важливі для науково-практичного розгляду функції Дисциплінарної комісії ДБР. У загальній теорії управління поняття «функція»є формою, способом прояву залежності між різними соціальними процесами в рамках цієї суспільної системи. Виділяються функції, без яких не може здійснюватися жоден управлінський цикл: аналіз, рішення, організація, регулювання, контроль і облік [41]. За твердженням O.I. Сушинського, «компетенція суб'єктів публічної служби завжди більш чітко закріплена у правовому полі, ніж функції, які лише частково визначені правовими нормами. Кожна інституція відповідно до своєї компетенції виконує притаманні їй функції. Компетенція визначає обсяг та зміст діяльності суб'єкта; здійснює розмежування функцій з іншими суб'єктами; встановлює певний розподіл функцій, які реалізуються публічної службою загалом. Функції суб'єкта публічної служби виявляються саме через сукупність усіх елементів компетенції. Функціями державних органів виступають основні напрями їх діяльності, в яких виявляється їх сутність і призначення в державному механізмі» [42, с. 12-13], що є цілком прийнятним й до Дисциплінарної комісії ДБР.

Дисциплінарна комісія ДБР здійснює такі функції:

1) розгляд матеріалів службових розслідувань про проступки працівників;

2) вироблення і внесення уповноваженому керівнику пропозицій з питань застосування видів стягнень.

Створення Дисциплінарної комісії ДБР для здійснення своєї діяльності відповідно до покладених на неї завдань передбачено ст. 25 Закону України від 12.11.2015 р. «Про Державне бюро розслідувань» [2], яка закріплює загальні положення щодо правових засад ïi утворення. Що стосується безпосередньо порядку створення Дисциплінарної комісії ДБР, ії завдань, функцій та порядку здійснення іiі діяльності, то вони визначаються спеціальним Положенням «Про Дисциплінарну комісію Державного бюро розслідувань», затвердженим Наказом ДБР від 06.01.2021 р. № 7 [43]. Варто зауважити, що Положення «Про Дисциплінарну комісію Державного бюро розслідувань», затверджене Наказом Державного бюро розслідувань від 07.10.2020 р. № 555 втратило чинність. Процедура здійснення дисциплінарними комісіями 3 розгляду дисциплінарних справ дисциплінарних проваджень стосовно державних службовців регулюється Порядком здійснення дисциплінарного провадження, затвердженим Постановою Кабінету Міністрів України від 04.12.2019 р. № 1039 [44]. У своїй діяльності Дисциплінарна комісія ДБР керується Конституцією України, Кодексом законів про працю України, Законом України від 12.11.2015 р. «Про Державне бюро розслідувань», Законом України від 10.12.2015 р. «Про державну службу», актами Президента України, Кабінету Міністрів України, іншими актами законодавства, Дисциплінарним статутом Національної поліції України під час розгляду питань застосування дисциплінарних стягнень до осіб рядового та начальницького складу ДБР. Дисциплінарна комісія ДБР створюється у складі п’яти осіб. Склад комісії затверджується наказом ДБР. До складу комісії входять дві особи, визначені директором ДБР або особою, яка виконує його повноваження з числа керівників самостійних структурних підрозділів центрального апарату ДБР, та три особи, визначені Радою громадського контролю при ДБР. 
Строк повноважень членів дисциплінарної комісії з числа керівників самостійних структурних підрозділів центрального апарату ДБР становить два роки. У свою чергу, строк повноважень членів дисциплінарної комісії з числа осіб, які визначаються Радою громадського контролю, не може перевищувати строку дії повноважень такого члена Ради. Так, згідно з Положенням «Про Раду громадського контролю», затвердженим Президентом України від 05.02.2020 р. № 42/2020 за поданням Директора Державного бюро розслідувань [45], Рада громадського контролю формується на засадах відкритого та прозорого конкурсу у складі 15 осіб строком на два роки. Строк повноважень Ради та ії членів розпочинається з дня проведення першого засідання Ради.

Очолює Дисциплінарну комісію ДБР голова, який визначається Директором ДБР з числа керівників самостійних структурних підрозділів центрального апарату. У разі відсутності голови Дисциплінарної комісії ДБР його повноваження виконує секретар. Секретар Дисциплінарної комісії ДБР визначається Директором ДБР з числа ії членів - працівників ДБР. 3 метою здійснення організаційного та матеріально-технічного забезпечення роботи Дисциплінарної комісії ДБР створюється робоча група, склад якої затверджується наказом ДБР.

Обговорення та прийняття рішення Дисциплінарною комісією ДБР відбувається в окремому приміщенні - нарадчій кімнаті, перебування у якій в цей час будь-яким іншим особам заборонено. Рішення приймається простою більшістю голосів присутніх членів, у разі рівного розподілу голосів вирішальним є голос голови Дисциплінарної комісії ДБР. Таким чином, слід відзначити вимого нормативно-правового характеру щодо місця і способу прийняття рішення.

Підсумовуючи вищезазначене, пропонуємо під адміністративно-правовим статусом Дисциплінарної комісії ДБР розуміти правове положення осіб у складі Дисциплінарної комісії ДБР, що визначається за допомогою закріплення у чинному адміністративному законодавстві мети іiї утворення та організації діяльності, завдань, функцій, компетенції та відповідальності, що дозволяє їй бути повноцінним учасником адміністративно-правових, у тому числі і службових, відносин. Основними структурними елементами адміністративно-правового статусу Дисциплінарної комісії ДБР є: мета іiі утворення; завдання, функції, компетенція та юридична відповідальність. Істотною рисою названих структурних елементів адміністративно-правового статусу Дисциплінарної комісії ДБР є урегульованість спеціальними нормами адміністративного права, їх самостійність (кожен із них має власне призначення), відносна стабільність у часі, взаємозв'язок і взаємозалежність один від одного.

\section{Jimepamypa:}

1. Загальне адміністративне право: підручник / Гриценко І.С., Мельник Р.С., Пухтецька А.А. та ін.; за заг. ред. І.С. Гриценка. К.: Юринком Інтер, 2015. 568 c.

2. Про Державне бюро розслідувань: Закон України від 12.11.2015 p. № 794-VIII. Відомості Верховної Ради Украӥни. 2016. № 6. Ст. 55.

3. Большой юридический словарь / под ред. А.Я. Сухарева, В.Е. Крутских. 2-е изд., перераб. и доп. М.: ИНФРА-М, 2003. $704 \mathrm{c}$.

4. Словник іншомовних слів / Уклад. С.М. Морозов, Л.М. Шкарапута. Київ: Наукова думка, 2000. 680 с.

5. Юридический энциклопедический словарь / М.М. Богуславский, М.И. Козырь, Г.И. Миньковский и др. М.: Сов. Энцклопедия, 1984. 415 c.
6. Новий український тлумачний словник / Близько 210000 слів i словосполучень / укл. Н.Д. Кусайкіна, Ю.С. Цибульник; за заг. ред. В.В. Дубічінського. Харків: Книжковий Клуб «Клуб сімейного дозвілля», 2008. $608 \mathrm{c}$.

7. Юридична енциклопедія: в 6 т. / редкол.: Ю.С. Шемшученко (гол. ред.) та ін. К.: Українська енциклопедія, 2003. Т. 5: П-С. 2003. $736 \mathrm{c}$.

8. Скакун О.Ф. Теорія держави і права: підручник. 2-ге вид. К.: Алерта; ЦУЛ, 2011. 520 с.

9. Волинка К.Г. Теорія держави і права: навчальний посібник. К.: МАУП, 2003. $240 \mathrm{c.}$

10. Теорія держави і права. Академічний курс: підручник. 2-е вид., перероб. і допов. / за ред. О.В. Зайчука, Н.М. Оніщенко. К.: Юрінком Інтер, 2008. 688 c.

11. Теория государства и права : курс лекций / А.В. Малько, Н.И. Матузов. М.: Юристь, 1997. 672 с.

12. Теорія держави та права : навчальний посібник / Є.В. Білозьоров, В.П. Власенко, О.Б. Горова, А.М. Завальний, Н.В. Заяць та ін. ; за заг. ред. С.Д. Гусарєва, О.Д. Тихомирова. К. : НАВС, Освіта України, 2017. $320 \mathrm{c}$.

13. Безпалова О.І., Горбач Д.О. Поняття та структура адміністративно-правового статусу Національної гвардії України. Форум права. 2017. № 5. C. 31-38,

14. Виконавча влада і адміністративне право : монографія / за заг. ред. В.Б. Авер'янова. К. : ВД «Ін Юре», 2002. 668 с.

15. Адміністративне право України: підручник / Ю.П. Битяк, В.М. Гаращук, О.В. Дьяченко та ін.; за ред. Ю.П. Битяка. К.: Юрінком Інтер, 2006. 544 с.

16. Адміністративне право України. Академічний курс: підручник: у 2-х томах: Том 1. Загальна частина / ред. колегія: В.Б. Авер'янов (голова). К.: Юридична думка, 2004. 584 с.

17. Зуй В.В. Адміністративно-правовий статус громадян в Україні. Правова держава Україна: проблеми, перспективи розвитку: зб. тез наук.-практ. конф. (м. Харків, 9-11 листопада 1995 року). Харків, 1995. С. 107-108.

18. Бандурка О.М. Адміністративне право України. Загальна частина: підручник. Харків : Золота миля, 2012. 584 с.

19. Стеценко С.Г. Адміністративне право України : навч. посіб. Вид. 3-те, перероб. та доп. К. : Атіка, 2011. 624 с.

20. Коломоєць Т.О. Адміністративне право України. Академічний курс : підручник. К. : «Юрінком Інтер», 2011. 576 с.

21. Адміністративне право України. Т.1. Загальне адміністративне право.: навчальний посібник / В.В. Галунько, В.І. Курило, С.О. Короїд та ін. ; за ред. проф. В.В. Галунька. Херсон : Грінь Д.С., 2015. $272 \mathrm{c}$.

22. Курило С.Л. Адміністративно-правовий статус органів внутрішніх справ як суб'єкта взаємодії з органами місцевої влади 3 питань забезпечення громадської безпеки та громадського порядку. Форум права: електронне наукове фахове видання. 2012. № 1. C. 523-526.

23. Моісєєв М.С. Адміністративно-правовий статус Державного бюро розслідувань України: дис. ... канд. юрид. наук : 12.00 .07 / Суми: СумДУ, 2019. 227 с.

24. Малиновський В.Я. Державне управління: навчальний посібник. Вид 2-ге, доп та перероб. Київ: Атіка, 2003. 576 с.

25. Адміністративне право України: підручник / за заг. ред. С.В. Ківалова. Одеса : «Юридична література», 2003. 896 с.

26. Ткаченко А.О. Поняття компетенції державного органу. Часопис Київського університету права. 2009. № 4. С. 192-197.

27. Венедиктов А.В. Государственная социалистическая собственность / Отв. ред. В.К. Райхекр. М.; Л.: Изд-во АН СССР, 1948. $840 \mathrm{c}$.

28. Тихомиров Ю.А. Теория компетенции. Журнал российского права., 2000. № 10. С. 22-32. 
29. Тихомиров Ю.А. Теория компетенции. М. : Юринформцентр, 2001. $355 \mathrm{c}$.

30. Пономарьов О.В. Адміністративно-правовий статус податкової міліції України: автореф. дис. на здобуття наук. ступеня канд. юрид. наук: 12.00.07. Київ. 2015. 16 с.

31. Солонар А.В. Окремі аспекти розкриття змісту поняття «повноваження». Порівняльно-аналітичне право. 2014. № 2. С. 253-256.

32. Карпа М.І. Розвиток публічної служби в Україні: компетенційний підхід : монографія. Львів : ЛРІДУ НАДУ, 2018. 262 с.

33. Великий тлумачний словник сучасної української мови / уклад. і гол. ред. В.Т. Бусел. К. ; Ірпінь : ВТФ «Перун», 2005. 1728 с.

34. Гнатюк С.С. Стадії провадження в справах про адміністративні проступки : дис. ... канд. юрид. наук : спец. 12.00.07 / Львів, 2010. $223 \mathrm{c}$.

35. Рогач О.Я. Кодифікаційні акти в системі законодавства України : дис. ... канд. юрид. наук : 12.00 .01 / Ужгород, 2003. 209 с.

36. Клюєв М.М. Кримінологічні засади програмування запобігання злочинності : дис. ... канд. юрид. наук : 12.00 .08 / К., 2008. 198 с.

37. Савенко М.Д. Правовий статус Конституційного Суду України: дис. .... канд. юрид. наук : 12.00 .02 / Х., 2001. 189 с.

38. Щербина В.І. Функції трудового права : дис. ... доктора юрид. наук : 12.00 .05 / Дніпропетровськ, 2008. 423 c.

39. Климков В.О. Організаційно-правові засади діяльності спеціального органу з питань банкрутства : дис. ... канд. юрид. наук : 12.00 .07 / K., 2010. 205 c.

40. Литвинов О.М. Соціально-правовий механізм протидії злочинності в Україні (теоретичні та практичні засади) : дис. ... доктора юрид. наук : 12.00 .08 / Х., 2010. 432 c.

41. Бачило И.Л. Функции органов управления (правовые проблемы формирования и реализации). М. : Юрид. лит., 1976. 200 с.

42. Публічна служба в Україні: концепція та практика регіональної кадрової політики : наук. розробка / О.І. Сушинський, О.В. Худоба, Д.Д. Заяць та ін. К. : НАДУ, 2013. 64 с.

43. Про Дисциплінарну комісію Державного бюро розслідувань: Положення, затверджене Наказом Державного бюро розслідувань від 06.01.2021 р. № 7. URL: https://dbr.gov.ua/assets/files/ documents/9.PDF

44. Про затвердження Порядку здійснення дисциплінарного провадження : Постанова Кабінету Міністрів України від 04.12.2019 p. № 1039. Офіційний вісник України. 2019. № 100. Ст. 3354.

45. Питання Ради громадського контролю при Державному бюро розслідувань: Указ Президента України від 05.02.2020 р. № 42/2020. Офіційний вісник України. 2020. № 14. Ст. 548.
Maksymovych A. Peculiarities of the administrative and legal status of the Disciplinary Commission of the State Bureau of Investigations

Summary. The article attempts to clarify the peculiarities of the administrative and legal status of the Disciplinary CommissionoftheStateBureauofInvestigation.Itissubstantiated that the need to study the peculiarities of the administrative and legal status of the Disciplinary Commission of the State Bureau of Investigation is also caused by the fact that this category reflects the specifics of the organization and activities of the Disciplinary Commission of the State Bureau of Investigation. In modern administrative and legal science, the subject of the study of the functioning of the Disciplinary Commission of the State Bureau of Investigation belongs to the poorly developed and undefined. Therefore, awareness of the theoretical and practical aspects of the administrative and legal status of the Disciplinary Commission of the State Bureau of Investigation necessitates the conduct of specialized research in this area. The definition of the concept of "administrative and legal status of the Disciplinary Commission of the State Bureau of Investigation" is given, it is proposed to single out structural elements in the composition of such status, their content is characterized. It is determined that the administrative and legal status of the Disciplinary Commission of the State Bureau of Investigation should be understood as the legal status of persons in the Disciplinary Commission of the State Bureau of Investigation, which is determined by the current administrative legislation. which allows her to be a full participant in administrative and legal, including official relations. The main structural elements of the administrative and legal status of the Disciplinary Commission of the State Bureau of Investigation are: the purpose of its formation; tasks, functions, competence and legal responsibility. An essential feature of these structural elements of the administrative and legal status of the Disciplinary Commission of the State Bureau of Investigation is the regulation of special rules of administrative law, their independence (each has its own purpose), relative stability over time, interconnection and interdependence.

Key words: discipline, service discipline, disciplinary responsibility, civil servant, employee of the State Bureau of Investigation, disciplinary misconduct, disciplinary sanction, administrative and legal regulation, administrative and legal status, disciplinary commission. 